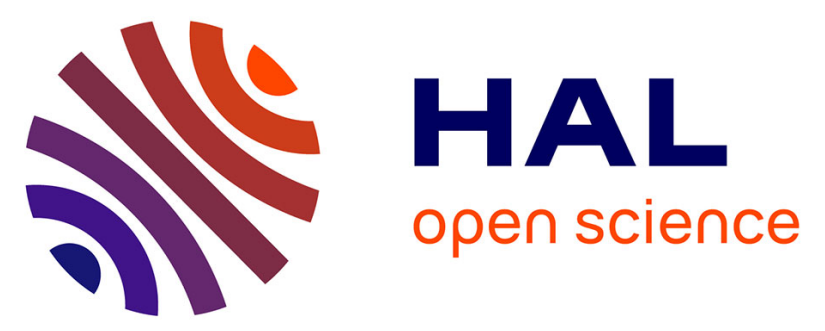

\title{
Effects of seasonal heat on the activity rhythm, habitat use, and space use of the beira antelope in southern Djibouti
}

Nina Giotto, Denis Picot, Marie-Line Maublanc, Jean-François Gérard

\section{- To cite this version:}

Nina Giotto, Denis Picot, Marie-Line Maublanc, Jean-François Gérard. Effects of seasonal heat on the activity rhythm, habitat use, and space use of the beira antelope in southern Djibouti. Journal of Arid Environments, 2013, 89, pp.5 - 12. 10.1016/j.jaridenv.2012.09.004 . hal-02647025

\section{HAL Id: hal-02647025 \\ https://hal.inrae.fr/hal-02647025}

Submitted on 29 May 2020

HAL is a multi-disciplinary open access archive for the deposit and dissemination of scientific research documents, whether they are published or not. The documents may come from teaching and research institutions in France or abroad, or from public or private research centers.
L'archive ouverte pluridisciplinaire HAL, est destinée au dépôt et à la diffusion de documents scientifiques de niveau recherche, publiés ou non, émanant des établissements d'enseignement et de recherche français ou étrangers, des laboratoires publics ou privés.

$$
\text { Copyright }
$$




\title{
Effects of seasonal heat on the activity rhythm, habitat use, and space use of the beira antelope in southern Djibouti
}

\author{
Nina Giotto *, Denis Picot, Marie-Line Maublanc, Jean-François Gerard \\ Comportement et Ecologie de la Faune Sauvage, Institut National de la Recherche Agronomique, BP 52627, F-31326 Castanet- \\ Tolosan Cedex, France \\ * Corresponding author. E-mail address: nina_giotto@hotmail.com
}

\begin{abstract}
In hot, arid environments, non-burrowing mammals are at risk of overheating and dehydration, so humaninduced reduction in thermal cover may constitute a threat for their survival. We studied the daytime activity rhythm, habitat use, and space use of the beira (Dorcatragus megalotis), a threatened antelope living in arid hills of the Horn of Africa, where tree cover is shrinking because of logging, and overgrazing by livestock. During the cool season (Nov.-Mar.; mean midday temperature: $28.5^{\circ} \mathrm{C}$ ), beira did not particularly seek shade, and alternated in the course of the day between short phases of activity and rest (median duration in Dec.-Feb.: 57.5 and $42.5 \mathrm{~min}$, respectively). In contrast, during the hot season (May-Sep.; mean midday temperature: $39.1^{\circ} \mathrm{C}$ ), beira often foraged in a hill's shade, and midday resting phases were especially long (median duration in May-Jul.: $280 \mathrm{~min}$ ) and spent in the shade of trees, or of rock shelters when available in the home range. Because of reduced diurnal movements when temperature was high, beira home ranges were smaller during the hot than during the cool season (mean $\pm S E$ : $0.25 \pm 0.05 \mathrm{~km}^{2}$ in May-Jul. vs $0.42 \pm 0.10 \mathrm{~km}^{2}$ in Dec.-Feb.). Whatever the season, beira mainly used areas supporting trees. The obtained results suggest that the decrease of tree cover in the areas inhabited by the beira constitutes a threat for the species survival.
\end{abstract}

Keywords: Conservation; Overgrazing; Thermoregulation; Threatened antelope; Tree logging

\section{Introduction}

In hot, arid and semi-arid environments, non-burrowing mammals are regularly exposed to high temperatures during the midday hours of the hot season. In such conditions, animals often reduce activity time and remain in cooler microhabitats (Leuthold, 1977; Estes, 1991; Skinner and Chimimba, 2005; Cain et al., 2006). This behaviour decreasing the risk of heat stress and dehydration, human-induced reduction in thermal cover may constitute a threat for the survival of a number of non-burrowing mammals inhabiting hot, dry environments. Such a threat is a priori more serious for small-bodied species because of their higher surface to mass ratio (Cain et al., 2006; Wilson and Krausman, 2008).

The only extant species in its genus, the beira (Dorcatragus megalotis) is a small-bodied Antilopini (Ropiquet et al., 2009) endemic to the arid, rocky hills and low elevation mountains of the Horn of Africa (northern Somalia, north-east Ethiopia, and southern Djibouti). Its distribution range has been reduced and fragmented since the beginning of the 20th century (Künzel and Künzel, 1998; Laurent et al., 2002; Giotto et al., 2009), and the beira is now classified as 'vulnerable' on the IUCN Red List of Threatened Species (Heckel et al., 2008). Even though local people sometimes hunt beira (Prévôt, 1993), the species' decline is assumed to result primarily from habitat loss and degradation (Heckel et al., 2008), as is the case for other wild ruminants (Jones, 1980; Haque and Smith, 1996; Pereladova et al., 1998; Stephens et al., 2001; Jenkins et al., 2002). Primary causes of degradation are overgrazing by domestic goats (Capra hircus), which reduces the amount of forage available during the dry season (Laurent et al., 2002; Giotto, 
2011), and the cutting of mature trees by local people to produce charcoal for domestic use (Giotto et al., 2009). The latter activity a priori reduces thermal cover availability. Its real effect, however, is unclear because the beira's rocky habitat may provide alternative sources of shade such as rock shelters (Giotto et al., 2008), and at least some species of the tribe Antilopini are able to survive in treeless environments by letting their body temperature increase during the hottest daytime hours, then dissipating the heat stored at night by non-evaporative means (Ostrowski and Williams, 2006).

In the present paper, we examine the effects of seasonal heat on the activity rhythm, habitat use, and space use of the beira. The purpose of the study was to assess whether the cutting of mature trees by local people could constitute a threat for the species.

\section{Study area, population and methods}

\subsection{Study area}

The study was conducted in a $4-\mathrm{km}^{2}$ area located in the rhyolitic rocky hills of Addaoua Bourale $\left(11^{\circ} 00^{\prime} \mathrm{N} ; 42^{\circ} 52^{\prime} \mathrm{E}\right)$ in the Ali-Sabieh region, southern Djibouti; elevation ranged from 600 to $850 \mathrm{~m}$. The area had a hot, arid climate, with a mean annual temperature $c a .30^{\circ} \mathrm{C}$, and an average $c a .250 \mathrm{~mm}$ rainfall per year (Laurent and Laurent, 2002). The months from November to March constituted a rather cool and wet season, with midday temperatures between 23 and $33^{\circ} \mathrm{C}$, night dews, and $c a .50 \%$ of the total annual rainfall. May to September constituted a hot and dry season, with midday temperatures between 37 and $42^{\circ} \mathrm{C}$, and $<25 \%$ of the total annual rainfall.

Vegetation cover in the study area was very sparse (Giotto, 2011), and mainly composed of small trees of Acacia etbaica ( $<2.5 \mathrm{~m}$ in height), shrubs of Iphionopsis rotundifolia, Croton somalensis, and Pulicaria somalensis, subshrubs of Seddera latifolia, the forb Aizoon canariense, and grasses including Cymbopogon schoenanthus. Overall, vegetation was intensely browsed by domestic goats belonging to the local community. Some domestic camels (Camelus dromedarius) also roamed the hills, and were occasionally sighted in the study area.

The beira, rock hyrax (Procavia johnstoni), and crested porcupine (Hystrix cristata) were the only wild herbivores having a body mass $>1 \mathrm{~kg}$ that lived in the hills of Addaoua Bourale. Rare caracals (Felis caracal) and leopards (Panthera pardus) were potential predators for adult beira. Young had additional predators: the striped hyena (Hyaena hyaena), the black-backed jackal (Canis mesomelas), the hamadryas baboon (Papio hamadryas), and Verreaux's eagle (Aquila verreauxii).

\subsection{Study population}

The study area encompassed the ranges of three beira socio-spatial units, and part of the range of a fourth (Giotto and Gerard, 2010). Each unit included a single adult male, from one to three adult females, and from zero to two younger individuals. The animals were untagged, but more than half of them were individually recognisable on the basis of colour pattern and morphology. In addition, the members of a unit made up a single group during most of the time, and the units' ranges were almost non-overlapping. Accordingly, observed individuals could be easily attributed to one of the socio-spatial units (Giotto and Gerard, 2010).

\subsection{Data collection}

Data were recorded between 8:00 and 18:00 (local time), during ten sessions of 12 days regularly distributed from late September 2006 to mid-July 2007, using 10x40 binoculars and a 20x spotting scope. Sixteen fixed observation points were distributed along three walking trails located on the upper third of the slopes. One trail was walked per day by the observer (NG), and the three trails were walked four times per 12-day session, alternatively in one direction then the other. The observer stayed for $1 \mathrm{~h}$ at an observation point then went to the next if no beira were sighted. Otherwise, each group sighted (solitary 
beira included) was monitored as long as possible, using the scan-sampling method (Altmann, 1974). Every 5 min the observer recorded (i) the group location on a map previously drawn using Garmin 12 GPS; (ii) the behaviour of each group member, classified as resting when laying or standing motionless, otherwise it was considered as active; (iii) whether the individual was in the shade of a hill, a tree or a rock (Fig. 1); and (iv) the vegetation type in which it was found. Four vegetation types were distinguished: (a) the patches supporting trees but no shrubs; (b) those supporting both trees and shrubs; (c) those supporting shrubs but no trees; and (d) the patches only supporting a very sparse herbaceoussubshrub layer. Every observation day, temperature was recorded at $c a$. 13:00 in the shade of a tree trunk. When a rock shelter was nearby, temperature was also measured at the same time in its shade. A total of 5664 scans, with an average of 3.26 individuals per scan, were recorded in the course of the study.

\subsection{Variation of ambient temperature}

Variation across observation sessions in the midday temperature recorded in the shade of trees was tested, using one-way anova. Moreover, the temperatures recorded at the same time in the shade of a tree and of a rock shelter were compared, using paired-sample $t$-test.

\subsection{Monthly variation of diurnal activity pattern}

The effect of the observation session on the diurnal activity pattern (i.e. the frequency with which beira were found to be active or resting as a function of the daytime hour) was tested using Pearson's $\chi^{2}$. To that aim, we computed the ten $\chi^{2}$-values measuring the effect of the observation session for the ten 1-h intervals included between 8:00 and 18:00. The sum of the ten values then gave us the $\chi^{2}$-value measuring the effect of the observation session on the diurnal activity pattern. However, because of the nonindependence of the data (recorded several times for the members of a same group during a single day), the obtained $\chi^{2}$-value could not be expected to follow a standard $\chi^{2}$ distribution. Accordingly, its $P$-value was estimated by permutation (Manly, 1997). We randomly permuted the labels 'session 1' to 'session 10' of the observation days, and recomputed the $\chi^{2}$-value. This operation was carried out 999 times, which gave us $999 \chi^{2}$-values under the null hypothesis that the observation session had no effect on the diurnal activity pattern. Finally, these $999 \chi^{2}$-values and that observed were ranked in decreasing order, and we computed the $P$-value as $P=r / 1000$, where $r$ is the rank of the observed value.

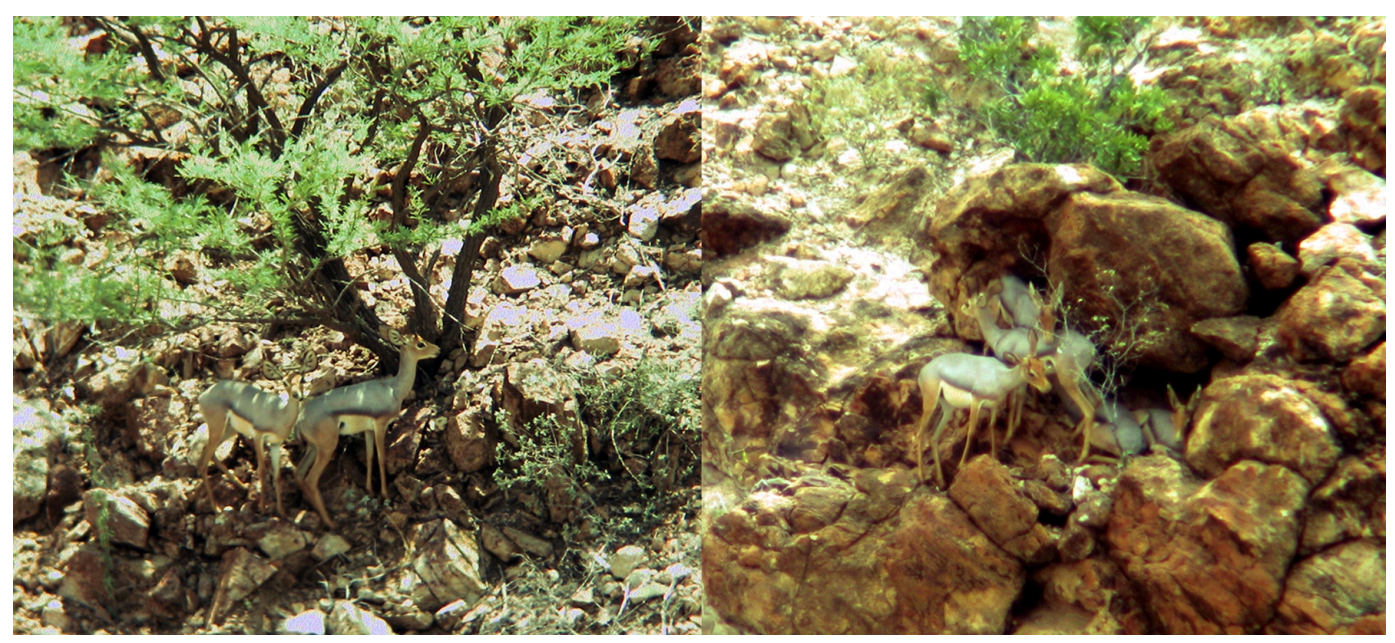

Fig. 1. Beira at rest in the shade of an Acacia etbaica and of a rock shelter. 


\subsection{Duration of the collective phases of activity and rest}

We examined the duration of the collective phases of activity and rest during the coolest and the hottest trimesters. Because group members were not always all active or all at rest, collective phases of activity and rest were defined as follows. (1) When surrounded by periods during which all the group members were active (/ resting), every time interval including both active and resting animals was considered as time of collective activity (/ rest). (2) When surrounded by a period during which all the members were resting and a period during which all were active, such an interval was cut into two parts of equal duration, one added to the period of collective resting, the other to the period of collective activity.

A number of phases were truncated because the monitoring of a group inevitably began and generally ended while the group was engaged in a phase of activity or rest. Accordingly, we used the Kaplan-Meier method to estimate the median phase duration, and used Cox's proportional hazards model for testing the effects of daytime and trimester (Cox and Oakes, 1984). These two techniques, ordinarily used for survival analysis, are suitable for samples including truncated durations. In the Cox's models fitted, daytime was coded as a five-level factor $(<10 \mathrm{~h} ; 10 \mathrm{~h}-12 \mathrm{~h} ; 12 \mathrm{~h}-14 \mathrm{~h} ; 14 \mathrm{~h}-16 \mathrm{~h} ;>16 \mathrm{~h})$, each level corresponding to a time interval to which a phase was attributed based on the time of the midpoint of the phase. The fitted models further included the socio-spatial unit as an additive factor, and the observation day as clustering factor.

\subsection{Monthly variation of shade use and habitat use}

The effect of the observation session on the frequency with which beira were located in or outside any shade (shade use), and the frequency with which they were found in the four vegetation types (habitat use) was tested using Pearson's $\chi^{2}$. Because of the non-independence of the data within observation days, the $P$-value of each test was estimated by random permutation, as described for the effect of the observation session on the diurnal activity pattern. The tests were performed separately for active and resting beira. In order to test for the difference between activity and rest in the use of a given habitat (or set of habitats), we compared the matching pairs of percentages obtained per observation session using paired-sample Wilcoxon test.

\section{Results}

\subsection{Midday temperature}

Mean midday temperature recorded in the shade of trees (Fig. 2) varied across observation sessions (one-way anova: $\left.F_{9,96}=153.16 ; P<0.0001\right)$. It was at its minimum in December $\left(25.9^{\circ} \mathrm{C}\right.$ ), with an overall mean of $26.8^{\circ} \mathrm{C}$ for the coolest trimester (Dec.-Feb.) and $28.5^{\circ} \mathrm{C}$ for the whole cool season (late Oct.-Mar.). It was maximum in June $\left(40.0^{\circ} \mathrm{C}\right)$, with an overall mean of $39.7^{\circ} \mathrm{C}$ for the hottest trimester (May-Jul.) and $39.1^{\circ} \mathrm{C}$ when including the temperatures recorded in late September-early October. On average $( \pm S E)$, midday temperature was $2.9( \pm 0.1){ }^{\circ} \mathrm{C}$ lower under rock shelters than in the shade of trees (paired-sample $t$-test: $t_{14}=31.55 ; P<0.0001$ ).

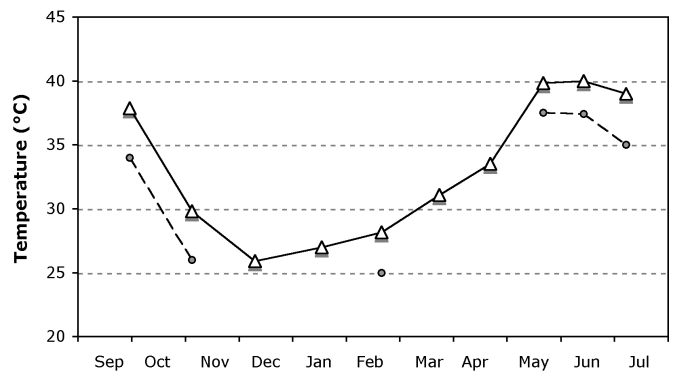

Fig. 2. Mean of the temperatures recorded on ca. 13:00 in the shade of a tree (white triangles) and under a rock shelter (grey circles) in the course of the ten 12-day observation sessions. 

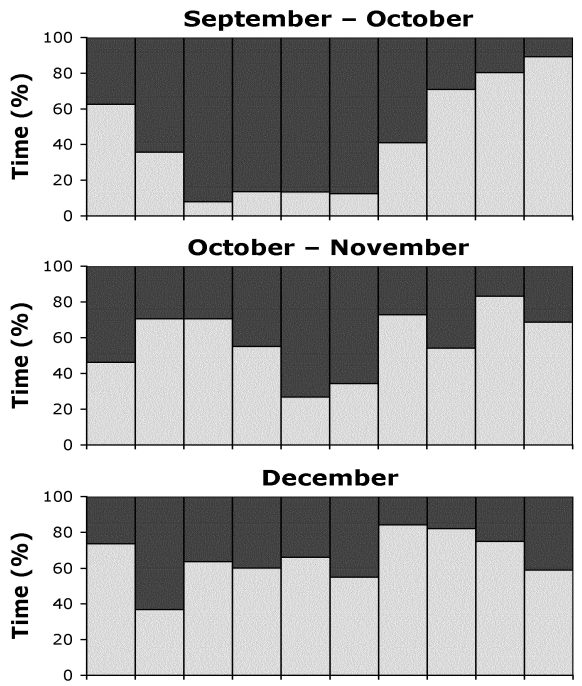

January

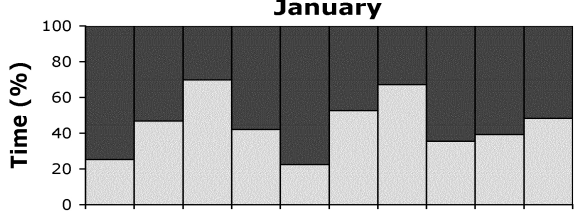

February

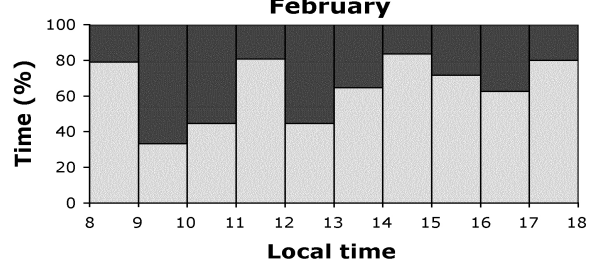

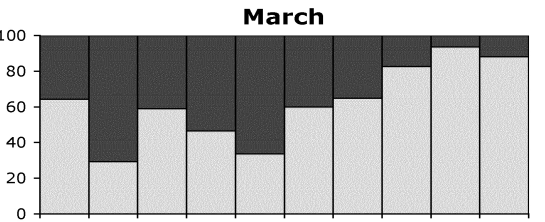

April

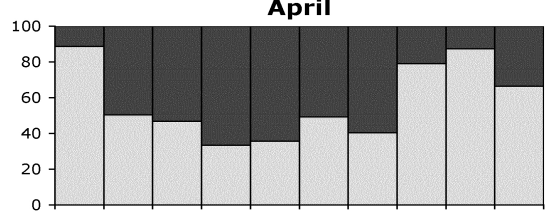

May

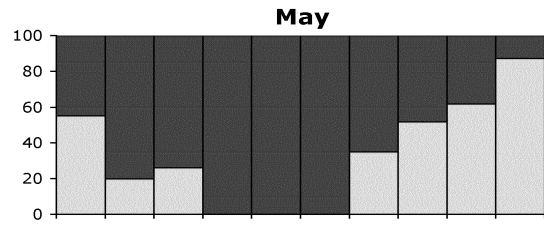

June

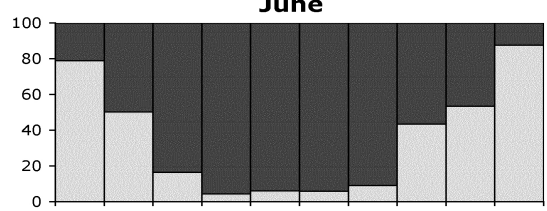

July

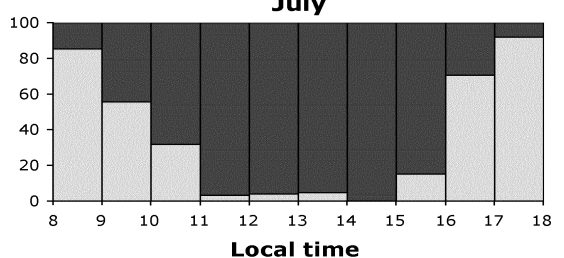

Fig. 3. Frequency with which beira were observed in activity (light grey) or at rest (dark grey) as a function of the daytime hour, for each observation session.

\subsection{Activity rhythm}

Diurnal activity pattern varied significantly across observation sessions $\left(\chi^{2}=3179.9\right.$; permutationestimated $P=0.002$ ). During the cool season, no clear periods of rest or activity emerged in the course of the day (late Oct.-early Nov. to Mar. in Fig. 3). In contrast, during the hot season, beira were almost exclusively at rest for 3-4 hrs during the middle of the day, and generally active at the beginning and the end of the day (May-Jul., and late Sep.--early Oct. in Fig. 3). April exhibited an intermediate pattern, with beira often active during the midday hours but less than during the remaining of the diurnal period.

The duration of the collective phases of rest and activity recorded during the coolest and hottest trimesters (Fig. 4) confirmed the contrast between the two seasons. The effect of daytime on phase duration depended on trimester (interaction daytime*trimester; resting phases: $\chi_{4}^{2}=26.55, P<0.0001$; activity phases: $\chi_{4}^{2}=14.11, P=0.007$ ). During the coolest trimester, phases of rest and activity (median duration: 42.5 and $57.5 \mathrm{~min}$, respectively) alternated in the course of the day without significant effect of daytime on their duration (rest: $\chi_{4}^{2}=6.60, P=0.16$; activity: $\chi_{4}^{2}=6.41, P=0.17$ ). During the hottest trimester, phase duration varied with time of day (rest: $\chi_{4}^{2}=20.60, P=0.0004$; activity: $\chi_{4}^{2}=28.36$, $P<0.0001)$. During this trimester, median duration of the resting phases was at a maximum in midday (280 $\mathrm{min})$ and minimum in the evening $(22.5 \mathrm{~min})$, and median duration of the activity phases was minimum in midday (10 $\mathrm{min})$ and maximum in the evening (>110 $\mathrm{min})$. 

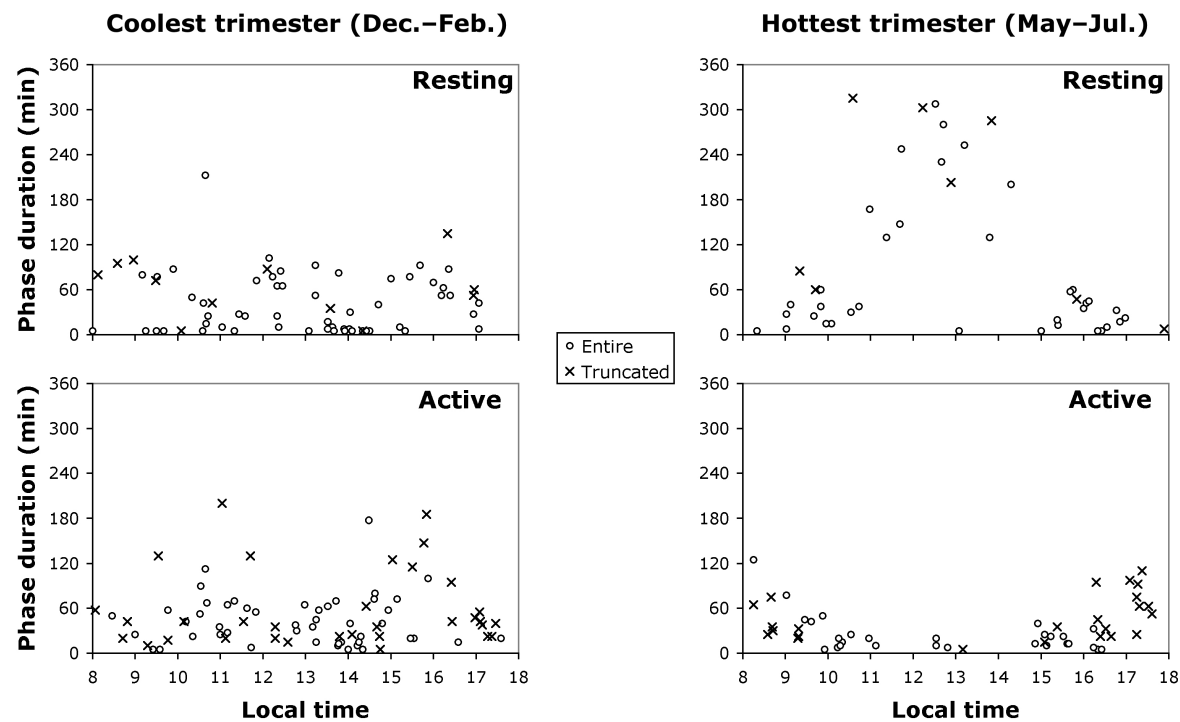

Fig. 4. Duration (in minutes) of the collective phases of rest and activity in the beira groups monitored during the coolest and hottest trimesters. White circles: entire phases; crosses: truncated phases.

\subsection{Shade use}

The frequency with which resting beira were located in the shade (Fig. 5a) greatly varied across observation sessions $\left(\chi^{2}=3360.8\right.$; permutation-estimated $\left.P=0.001\right)$ and was strongly correlated to mean midday temperature (Spearman rank correlation: $r_{s}=0.903, n=10 ; P<0.001$ ). Shade was primarily provided by trees $(62 \%$ of all the locations in the shade). However, in May-July, when mean midday temperature exceeded $38^{\circ} \mathrm{C}$, beira often rested in the shade of rock shelters when such shelters were available in their home range (58\% of the locations in the shade). The frequency with which active beira were located in the shade of a hill (Fig. 5b) also varied across observation sessions $\left(\chi^{2}=2773.5\right.$; permutation-estimated $P=0.001$ ), with high values during the hot season (May-Jul. and late Sep.-early Oct.), and low values outside.

(a) Resting

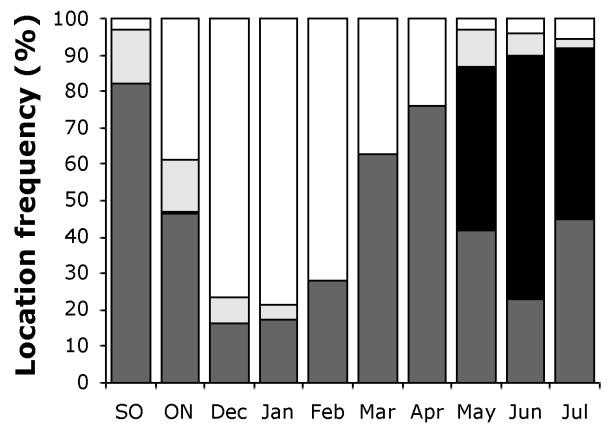

(b) Active

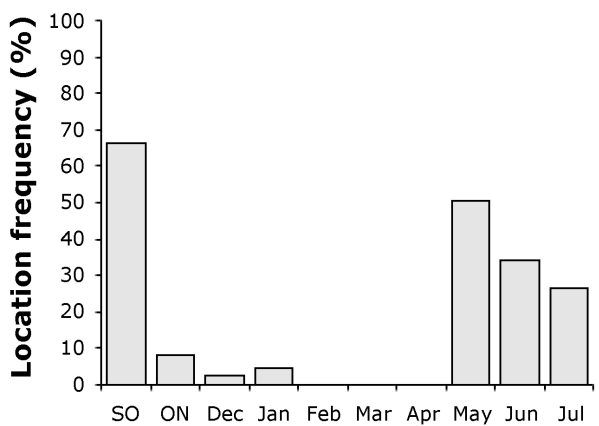

Fig. 5. (a) Frequency with which resting beira were located outside any shade, in a hill's shade, in a rock shelter' shade, or a tree's shade. (b) Frequency with which active beira were located in a hill's shade.

Each column corresponds to a 12-day observation session. 
(a) Resting

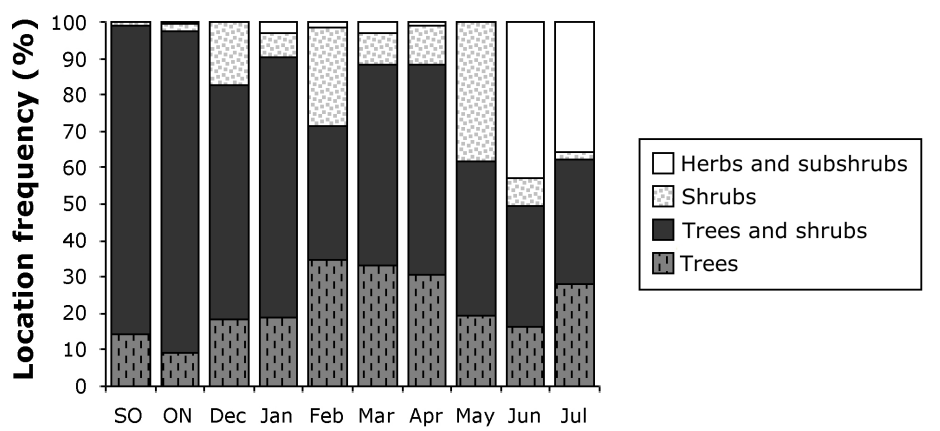

(b) Active

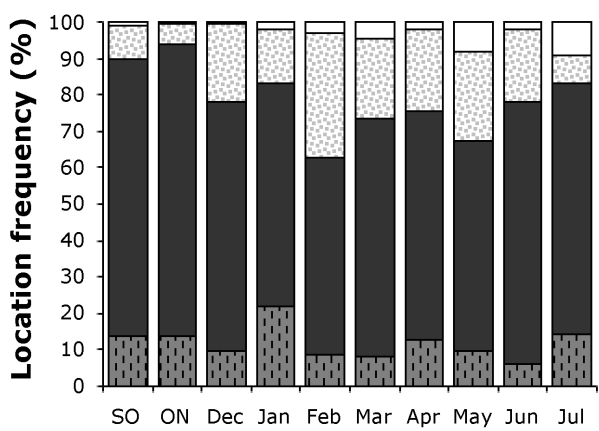

Fig. 6. Frequency with which (a) resting and (b) active beira were located in the different vegetation types for each observation session.

\subsection{Habitat use}

Beira were primarily located in patches supporting trees (mean percentage per session $\pm S E$ : $79.0 \pm 5.3 \%$ in resting animals, $78.5 \pm 3.0 \%$ in active animals; paired-sample Wilcoxon test: $T=33, n=10$, $P=0.625)$. These patches with trees were more often devoid of shrubs in resting than in active animals (mean percentage per session $\pm S E: 29.7 \pm 4.1 \%$ in resting animals, $15.0 \pm 1.5 \%$ in active animals; pairedsample Wilcoxon test: $T=49, n=10, P=0.0273$ ). Furthermore, frequency of location in the four habitats varied significantly across observation sessions (resting animals: $\chi^{2}=3992.2$, permutation-estimated $P=0.028$; active animals: $\chi^{2}=805.3$, permutation-estimated $P=0.042$ ). Overall, the use of patches without trees increased from late September-early October to February (Fig. 6). Beyond February, it decreased then increased again in May-July in resting animals because the rock shelters used at that time for rest were generally located on rocky grounds without trees.

\subsection{Space use}

Home ranges of the three socio-spatial units entirely included in the study area were smaller during the hottest than during the coolest trimester (Fig. 7; mean area $\pm S E: 0.25 \pm 0.05 \mathrm{~km}^{2} v S 0.42 \pm 0.10 \mathrm{~km}^{2}$ ). However, the animals' spatial behaviour differed between units during the hottest trimester: the routes recorded for units $\mathrm{A}$ and $\mathrm{B}$ were tortuous and concentrated near favourite resting sites, whereas those recorded for unit $\mathrm{C}$ were longer and rather paralleled (Fig. 7b). The members of the latter unit foraged early in the morning on a shaded, west-facing slope; they often rested there in a rock shelter during midday hours. In the afternoon, they crossed the crest line and frequently remained active on the now shaded, east-facing slope.

\section{Discussion}

There were noticeable effects of seasonal heat on the daytime activity rhythm, habitat use, and space use of the beira. In the cool season, the observed animals alternated throughout the day between short phases of activity and rest, a rhythm typically found in small-bodied ruminants (Hofmann, 1973; Walther, 1973; Cederlund, 1989; Van Soest, 1996; Zhang, 2000). In the same season, the animals sought little shade, and often moved over rather long distances during daytime. In contrast, in the hot season, beira remained inactive in the shade during several consecutive midday hours. In addition, they generally restricted their diurnal movements to the vicinity of resting sites, except when using different parts of their range where they could forage on shaded hillsides. In both cases, diurnal range was smaller than in the cool season. 

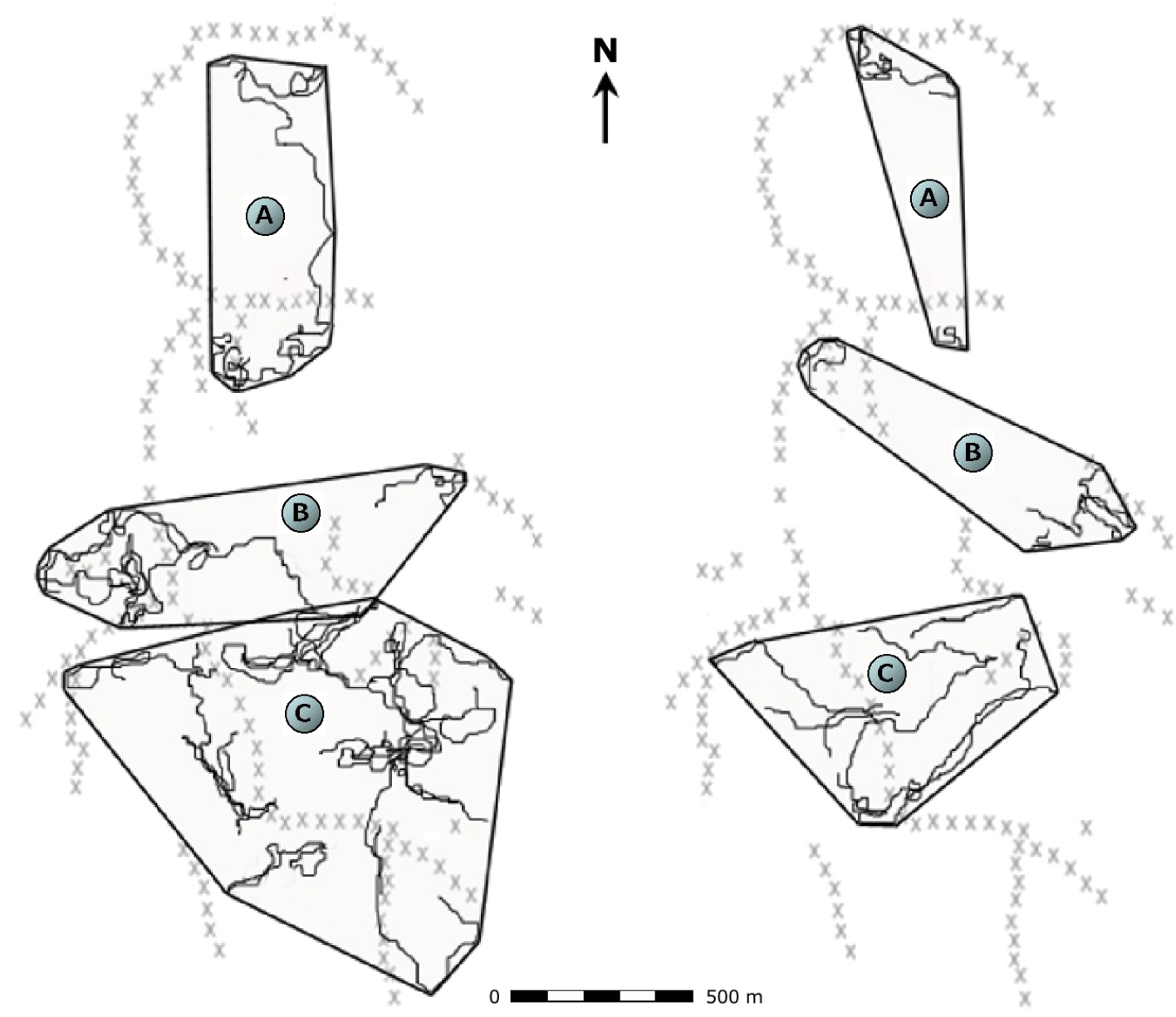

Fig. 7. Home ranges of the beira socio-spatial units A, B, and C during (a) the coolest and (b) the hottest trimester. Respective areas: $0.32,0.32$, and $0.61 \mathrm{~km}^{2}$ for the coolest trimester; $0.16,0.24$, and $0.34 \mathrm{~km}^{2}$ for the hottest trimester. Sinuous lines: routes of the different groups monitored during the corresponding trimesters; grey crosses: crest.

The effects of seasonal heat on the activity pattern and shade use of the beira are consistent with findings reported for many other large mammalian herbivores inhabiting hot, arid and semi-arid environments (Jarman and Jarman, 1973; Berger, 1977; Leuthold, 1977; Lewis, 1978; Simmons, 1980; Owen-Smith 1988, 1998; Estes, 1991; Roberts and Dunbar, 1991; Bohra et al. 1992; Sargeant et al., 1994; Manser and Brotherton, 1995; Ostrowski et al., 2003; Maloney et al., 2005; du Toit and Yetman, 2005; Matson et al., 2005; Skinner and Chimimba, 2005; Cain et al., 2006; Valdez, 2011). In contrast, the results obtained with respect to space use do not, and can hardly, correspond to a general pattern. Depending on the region, ambient temperature peaks either during the dry or the wet season, and thus at a time of shortage or abundance of high-quality forage and water. Furthermore, seasonal change in food and water availability has contrasting effects on daily movements and range size, depending on the species' mobility, feeding style and water dependency, as well as the landscape structure, and the habitat use (Jarman, 1974; Leuthold, 1977; Williamson and Williamson, 1988; Owen-Smith and Cain, 2007; Cain et al., 2012). A number of mobile browsers living in heterogeneous landscape tend to disperse and/or range extensively during the wet season in search of preferred food items, and restrict their space 
use to smaller areas where browse and water remain available in the dry season (Goddard, 1967; Leuthold and Leuthold, 1978; Owen-Smith, 1979: 104; Rautenstrauch and Krausman, 1989; Clemente et al., 1995). In contrast, several mobile grazers tend to increase the distance travelled per hour of activity and their range size during the food shortage of the dry season (Joubert, 1972; Owen-Smith, 1988; Ryan et al., 2006; Owen-Smith and Cain, 2007), provided the individuals are not restricted in their space use by their need of water and the distribution of this resource (Berger, 1977; Pienaar et al., 1993; Funston et al., 1994). Like the beira (Giotto and Gerard, 2010; Giotto, 2011), the dik-diks (Madoqua spp.), steenbok (Raphicerus campestris), klipspringer (Oreotragus oreotragus), and common duiker (Sylvicapra grimmia) are water-independent browsers having a reduced mobility because of their small body size and socio-spatial organisation largely based upon territoriality (Estes, 1991; Skinner and Chimimba, 2005). Restriction of daily movements and concomitant decrease in diurnal range size when ambient temperature becomes high is probably common among these herbivores, though certainly not universal. During the dry season, klipspringers have been reported to temporarily leave their territories established on an isolated rocky area (Groves, 2011), or extend their home range to forage in outer feeding sites (Estes, 1991). Such behaviour cannot be entirely excluded in beira living on a massif's margin or occupying rather isolated hills, especially in the event of severe drought.

The effects of seasonal heat on the beira's activity rhythm, habitat use, and space use show the species' sensitivity to high ambient temperatures. The fact that the observed animals often used rock shelters during the hottest months, while mean midday temperature exceeded $38^{\circ} \mathrm{C}$, is especially significant. Use of caves and rocky overhangs during the hot midday hours has been reported in some large herbivores (Krausman, 1979; Simmons, 1980), and the thermal advantage provided by such microhabitats over tree cover has been pointed out (Cain et al., 2008). As rock shelters were rare within our study area, their intensive use by the beira illustrates their importance for beira when ambient temperature becomes too high. According to Hammer (pers. comm.), the captive beira from Al Wabra Wildlife Preservation, Qatar, exhibit increased panting as soon as ambient temperature exceeds $35^{\circ} \mathrm{C}$. In such conditions, the animals remain in the air-conditioned houses they have at their disposal in their enclosures. Before the building of these artificial shelters, several deaths occurred among the captive beira because of extreme heats (Hammer, 2011).

Whereas rock shelters were clearly privileged resting sites during the hottest months of the year, trees are also a major and important source of shade for the beira. Because of their scarcity in typical beira habitat, rock shelters can hardly replace trees. In the present study, unit B did not have any rock shelter at its disposal within its home range. Use of the only rock shelters would further impose to the animals a very heterogeneous use of space, and therefore of the trophic resources during a large part of the annual cycle. Trees, in the form of seedlings, are a main food item for the beira (Giotto, 2011). In addition, mature trees constitute an irreplaceable source of shade over most of the species' range. With this respect, overgrazing by domestic goats and the cutting of mature trees for charcoal production considerably reduce habitat quality for the beira, and should be considered as real threat for the species' survival in its natural habitat.

\section{Acknowledgements}

Special thanks are due to Abo Daher Obsieh, Walalo Nicolas Prévôt as well as to the shepherds of Assamo for their great hospitality. We are grateful to the SCAC/MAE (Service de Coopération et d'Action Culturelle du Ministère des Affaires Etrangères), zoo of Landau, ZGAP (Zoologische Gesellschaft für Arten- und Populationsschutz e.V.), CEPA (Conservation des Espèces et Populations Animales), and ABCR (Association Beauval Conservation and Research) for supporting this study. We thank Catrin Hammer, formerly from Al Wabra Wildlife Preservation, for providing us information on the behaviour of captive beira. Our acknowledgements also go to Bertrand Lafrance from DECAN (DECouvrir et Aider la Nature), and Alain Laurent (TER_RES/Beira.cfp) for helping us in the concretisation of this work. Finally, we gratefully acknowledge James Cain and an anonymous reviewer for their useful comments and suggestions. The whole study complies with current Djiboutian laws. 


\section{References}

Altmann, J., 1974. Observational study of behavior: sampling methods. Behaviour 49, 227-267.

Berger, J., 1977. Organizational systems and dominance in feral horses in the Grand Canyon. Behavioral Ecology and Sociobiology 2, 131-146.

Bohra, H. C., Goyal S. P., Ghosh, P. K. and Prakash, I. 1992. Studies on ethology and eco-physiology of antelopes of the Indian desert. Annals of Arid Zone 31, 83-96.

Cain III, J.W., Krausman, P.R., Rosenstock, S.S., Turner, J.C., 2006. Mechanisms of thermoregulation and water balance in desert ungulates. Wildlife Society Bulletin 34, 570-581.

Cain, J.W., Jansen, B.D., Wilson, R.R., Krausman, P.R., 2008. Potential thermoregulatory advantages of shade use by desert bighorn sheep. Journal of Arid Environments 72, 1518-1525.

Cain III, J.W., Owen-Smith, N., Macandza, V.A., 2012. The costs of drinking: comparative water dependency of sable antelope and zebra. Journal of Zoology 286, 58-67.

Cederlund, G., 1989. Activity patterns in moose and roe deer in a north boreal forest. Holarctic Ecology 12, 39-45.

Clemente, F., Valdez, R., Holechek, J.L., Zwank, P.J., Cardenas, M., 1995. Pronghorn home range relative to permanent water in southern New Mexico. The Southwestern Naturalist 40, 38-41.

Cox, D.R., Oakes, D., 1984. Analysis of survival data. Chapman and Hall, London.

du Toit, J.T., Yetman, C.A., 2005. Effects of body size on the diurnal activity budgets of African browsing ruminants. Oecologia 143, 317-325.

Estes, R.D., 1991. The behavior guide to African mammals. University of California Press, Berkeley.

Funston, P.J., Skinner, J.D., Dott, H.M., 1994. Seasonal variation in movement patterns, home range and habitat selection of buffaloes in a semi-arid habitat. African Journal of Ecology 32, 100-114.

Giotto, N., 2011. Eco-éthologie et conservation du Beira (Dorcatragus megalotis) en République de Djibouti. PhD thesis, University of Toulouse III, Toulouse.

Giotto, N., Gerard, J.-F., 2010. The social and spatial organisation of the beira antelope (Dorcatragus megalotis): a relic from the past? European Journal of Wildlife Research 56, 481-491.

Giotto, N., Laurent, A., Mohamed, N., Prévôt, N., Gerard, J.-F., 2008. Observations on the behaviour and ecology of a threatened and poorly known dwarf antelope: the beira (Dorcatragus megalotis). European Journal of Wildlife Research 54, 539-547.

Giotto, N., Obsieh, D., Joachim, J., Gerard, J.-F., 2009. Population size and distribution of the vulnerable beira antelope Dorcatragus megalotis in Djibouti. Oryx 43, 552-555.

Goddard, J. 1967. Home range, behaviour, and recruitment rates of two black rhinoceros populations. East African Wildlife Journal 5, 133-150.

Groves, C.P. 2011. Tribe Oreotragini genus Oreotragus. A. Smith, 1834. In: Wilson, D.E., Mittermeier, R.A. (Eds), Handbook of the mammals of the world, 2 Hoofed mammals. Lynx, Barcelona, pp. 777-779.

Haque, M.N., Smith, T.R., 1996. Reintroduction of Arabian sand gazelle Gazella subgutturosa marica in Saudi Arabia. Biological Conservation 76, 203-207.

Hammer, C., 2011. Ex situ management of beira antelope Dorcatragus megalotis at Al Wabra Wildlife Preservation, Qatar. International Zoo Yearbook, 45:259-273.

Heckel, J.O., Rayaleh, H.A., Wilhelmi, F., Hammer, S., 2008. Dorcatragus megalotis. In 2008 IUCN Red List of Threatened Species (ed IUCN). Http://www.iucnredlist.org [accessed 19 November 2008].

Hofmann, R.R. 1973. The ruminant stomach: stomach structure and feeding habits of East African game ruminants. East African Literature Bureau, Nairobi.

Jarman, P.J., 1974. The social organisation of antelope in relation to their ecology. Behaviour 48, 215-267.

Jarman, M.V., Jarman, P.J., 1973. Daily activity of impala. East African Wildlife Journal 11, 75-92.

Jenkins, R.K.B., Corti, G.R., Fanning, E., Roettcher, K., 2002. Management implications of antelope habitat use in the Kilombero Valley, Tanzania. Oryx 36, 161-169.

Jones, F.L., 1980. Competition. In: Monson, G., Sumner, L. (Eds.), The desert bighorn: its life history, ecology and management. University of Arizona Press, Tucson, pp. 197-216.

Joubert, E., 1972. The social organization and associated behaviour in the Hartmann zebra Equus zebra hartmannae. Madoqua Series I 6, 17-56.

Krausman, P.R., 1979. Use of caves by white-tailed deer. The Southwestern Naturalist 24, 203.

Künzel, T., Künzel, S., 1998. An overlooked population of the beira antelope Dorcatragus megalotis in Djibouti. Oryx $32,75-80$.

Laurent, A., Laurent, D., 2002. Djibouti au rythme du vivant: les mammifères d'hier à aujourd'hui pour demain. Beira.CFP, Toulouse. 
Laurent, A., Prévôt, N., Mallet, B., 2002. Original data in ecology, behaviour, status, historic and present distribution of the Beira Dorcatragus megalotis (Bovidae: Antilopinae) in the Republic of Djibouti and adjacent territories of Somalia and Ethiopia. Mammalia 66, 1-16.

Leuthold, W., 1977. African ungulates: a comparative review of their ethology and behavioral ecology. SpringerVerlag, Berlin.

Leuthold, B.M., Leuthold, W., 1978. Ecology of the giraffe in Tsavo East National Park, Kenya. East African Wildlife Journal 16, 1-20.

Lewis, J.G., 1978. Game domestication for animal production in Kenya: shade behaviour and factors affecting the herding of eland, oryx, buffalo and zebu cattle. Journal of Agricultural Science 90, 587-595.

Maloney, S.K., Moss, G., Cartmell, T., Mitchell, D., 2005. Alteration in diel activity patterns as a thermoregulatory strategy in black wildebeest (Connochaetes gnou). Journal of Comparative Physiology A 191, 1055-1064.

Manly, B.F.J., 1997. Randomization, bootstrap and Monte Carlo methods in Biology, second ed. Chapman and Hall, London.

Manser, M.B., Brotherton, P.N.M., 1995. Environmental constraints on the foraging behaviour of a dwarf Antelope (Madoqua kirkii). Oecologia 102, 404-412.

Matson, T.K., Goldizen, A.W., Jarman, P.J. 2005. Microhabitat use by black-faced impala in the Etosha National Park, Namibia. Journal of Wildlife Management 69, 1708-1715.

Mohr, C.O., 1947. Table of equivalent populations of North American small mammals. American Midland Naturalist 37, 223-249.

Ostrowski, S., Williams, J.B., Ismael, K., 2003. Heterothermy and the water economy of free-living Arabian oryx (Oryx leucoryx). Journal of Experimental Biology 206, 1471-1478.

Ostrowski, S., Williams, J.B., 2006. Heterothermy of free-living Arabian sand gazelles (Gazella subgutturosa marica) in a desert environment. Journal of Experimental Biology 209, 1421-1429.

Owen-Smith, N., 1979. Assessing the foraging efficiency of a large herbivore, the kudu. South African Journal of Wildlife Research 9, 102-110.

Owen-Smith, R.N., 1988. Megaherbivores: the influence of very large body size on ecology. Cambridge University Press, Cambridge.

Owen-Smith, N., 1998. How high ambient temperature affects the daily activity and foraging time of a subtropical ungulate, the greater kudu (Tragelaphus strepsiceros). Journal of Zoology 246, 183-192.

Owen-Smith, N., Cain III, J.W., 2007. Indicators of adaptive responses in home range utilization and movement patterns by a large mammalian herbivore. Israel Journal of Ecology and Evolution 53, 423-438.

Pereladova, O.B., Bahloul, K., Sempéré, A.J., Soldatova, N.V., Schadilov, U.M., Prisiadznuk, V.E., 1998. Influence of environmental factors on a population of goitered gazelles (Gazella subgutturosa subgutturosa Güldenstaedt, 1780) in semi-wild conditions in an arid environment: a preliminary study. Journal of Arid Environments 39, 577-591.

Pienaar, D.J., Bothma, J. du P., Theron, G.K., 1993. White rhinoceros range size in south-western Kruger National Park. Journal of Zoology 229, 641-649.

Prévôt, N., 1993. Etude du Dorcatragus megalotis dans la petite région d'Ali-Sabieh, Djibouti. Rapport d'activité ONTA, Projet U.E.B7 50-40/91/024.

Rautenstrauch, K.R., Krausman, P.R., 1989. Influence of water availability and rainfall on movements of desert mule deer. Journal of Mammalogy 70, 197-201.

Roberts, S.C., Dunbar, R.I.M., 1991. Climatic influences on the behavioural ecology of Chanler's mountain reedbuck in Kenya. African Journal of Ecology 29, 316-329.

Ropiquet, A., Li, B., Hassanin, A., 2009. SuperTRI: a new approach based on branch support analyses of multiple independent data sets for assessing reliability of phylogenetic inferences. Comptes Rendus Biologies 332, $832-847$.

Ryan, S.J., Knechtel, C.U., Getz, W.M., 2006. Range and habitat selection of African buffalo in South Africa. Journal of Wildlife Management 70, 764-776.

Sargeant, G.A., Eberhardt, L.E., Peek, J.M., 1994. Thermoregulation by mule deer (Odocoileus hemionus) in arid rangelands of southcentral Washington. Journal of Mammalogy 75, 536-544.

Simmons, N.M., 1980. Behavior. In: Monson, G., Sumner, L. (Eds.), The desert bighorn: its life history, ecology and management. University of Arizona Press, Tucson, pp. 124-144.

Skinner, J.D., Chimimba, C.T., 2005. The mammals of the Southern African subregion. Cambridge University Press, Cambridge. 
Stephens, P.A., d'Sa, C.A., Sillero-Zubiri, C., Leader-Williams, N., 2001. Impact of livestock and settlement on the large mammalian wildlife of Bale Mountains National Park, southern Ethiopia. Biological Conservation 100, $307-322$.

Valdez, R. 2011. Nubian ibex Capra nubiana. In: Wilson, D.E., Mittermeier, R.A. (Eds), Handbook of the mammals of the world, 2 Hoofed mammals. Lynx, Barcelona, pp. 721-722.

Van Soest, P.J., 1996. Allometry and ecology of feeding behavior and digestive capacity in herbivores: a review. Zoo Biology 15, 455-479.

Walther, F.R., 1973. Round-the-clock activity of Thomson's gazelle (Gazella thomsoni Günther 1884) in the Serengeti National Park. Zeitschrift für Tierpsychologie 32, 75-105.

Williamson, D., Williamson, J., 1988. Habitat use and ranging behaviour of Kalahari gemsbok (Oryx gazella Linnaeus, 1758). In: Dixon, A., Jones, D. (Eds.), Conservation and biology of desert antelopes. Christopher Helm, London, pp. 114-118.

Wilson, R.R., Krausman, P.R., 2008. Possibility of heat-related mortality in desert ungulates. Journal of the ArizonaNevada Academy of Science 40, 12-15.

Zhang, E., 2000. Ingestive behaviour of the Chinese water deer. Zoological Research 21, 88-91. 